\section{Australian Journal of \\ Crop Science}

\title{
Water deficit detection in sugarcane using canopy temperature from satellite
} images

\author{
Rodrigo Moura Pereira ${ }^{1}$, Derblai Casaroli* ${ }^{2}$, Lucas Melo Vellame ${ }^{3}$, José Alves Júnior ${ }^{4}$, Adão Wagner Pêgo \\ Evangelista ${ }^{4}$, Rafael Battisti ${ }^{4}$
}

\author{
${ }^{1}$ Federal University of Brasília (UnB), Campus Darcy Ribeiro, 70910-900, Brasília, DF, Brazil \\ ${ }^{2}$ Federal University of Goiás (UFG), College of Agronomy, Esperança avenue, Campus Samambaia, 74690- \\ 900, Goiânia, GO, Brazil \\ ${ }^{3}$ Federal University of Bahia Recôncavo (UFRB), Rui Barbosa street, Cruz das Almas, BA, Brazil, 44380-000. \\ ${ }^{4}$ UFG, Brazil
}

*Corresponding author: derblai@ufg.br; ORCID: https://orcid.org/0000-0001-8041-0066

\section{Abstract}

Water deficit (WD) is the main yield gap for sugarcane in Midwest Brazil. Thus, WD detection is essential to quantify yield losses, but field detection requires measurement of soil water content over large areas. In this study, we tested leaf temperature $\left(T_{L}\right)$ and land surface temperature $\left(T_{s}\right)$ to detect WD in a commercial sugarcane area. The area is located in the central region of Goiás State, Brazil. According to Köppen classification, the climate of the region is Aw (humid tropical, with rainy summer and dry winter). The soil is a Ferralsol (clayey texture). $T_{L}$ was measured by a portable infrared thermometer, and $T_{S}$ was obtained using a spectral image from Landsat 8. Both $T_{L}$ and $T_{S}$ measurements occurred between 28 Jan and 24 Aug 2014 (298-506 DAP). The water balance identified periods of water deficit (WD) and surplus (WS). The difference between $\mathrm{T}_{\mathrm{L}}-\mathrm{T}_{\mathrm{a}}$ was greater than zero $\left(7.11^{\circ} \mathrm{C}\right)$ in WD periods and lower than zero $\left(-2.18{ }^{\circ} \mathrm{C}\right)$ in WS periods. The difference between $\mathrm{T}_{\mathrm{s}} \mathrm{T}_{\mathrm{a}}$, in turn, ranged from $-0.66^{\circ} \mathrm{C}$ to $4.06{ }^{\circ} \mathrm{C}$, but not following the tendency of WD or WS, which is associated with a relative error between $T_{L}$ and $T_{S}$ near $20 \%$ for some date. The $T_{S}-T_{a}$ difference detected soil WD or WS when the relative error was low (362 and 410 DAP) and under higher WD (506 DAP) and WS (394 DAP). This way, $T_{L}$ was able to detect WD and WS along sugarcane growth, while $T_{S}$ showed limited application, requiring improvement based on surface properties to reduce the error in relation to $T_{L}$. Furthermore, bands 10 and 11 are recommended for surface temperature estimation. Calibration uncertainty increases when the band 11 is used alone, being this band more affected by the absorption of radiation by the atmospheric water vapor, which implies larger errors related to the atmospheric profile in the acquisition of surface temperature.

Keywords: Saccharum spp., Landsat-8, spectral image, remote sensing, drought.

Abbreviations: DAP _ days after planting; $T_{\mathrm{a}}$ - Air temperature; $\mathrm{T}_{\mathrm{S}_{-}}$Land surface temperature; $\mathrm{T}_{\mathrm{L}}$ L Leaf temperature; TB10 _ band 10; TB11_band 11; WD _ Water deficit; WS _ Water surplus.

\section{Introduction}

Sugarcane was grown in 8.7 million ha in the 2017/18 crop season in Brazil. Of these, the Midwest region accounted for 1.8 million ha, and Goiás State accounted for near 1 million ha (CONAB, 2018). The Midwest region has a water deficit occurring mainly in the winter, with low rainfall during about 7 months per year (Alvares et al., 2013). In this region, there is a huge yield gap caused by water deficit in sugarcane crop due to the longer cycle. The yield gap by water deficit represents $68.6 \%$ of the total yield gap in the Midwest, while in Goiás State, this value reached $76.4 \%$ (Monteiro and Sentelhas, 2017).

The crop has a physiological mechanism to withstand a period of water deficit, e.g., the stomatal closure (Gilbert et al., 2011). Moreover, there are different levels of adaptation and yield reductions (Sousa et al., 2017). As a consequence of that, the crop reduces transpiration and increases leaf temperature (Gerhards et al., 2016). Leaf temperature can be between 1 and $4{ }^{\circ} \mathrm{C}$ below air temperature if the crop is under no water limitation (López et al., 2009). Otherwise, under water deficit stress, the leaf temperature has a gradual increase, reaching between 4 and $6{ }^{\circ} \mathrm{C}$ above air temperature (López et al., 2009).

The difference between leaf and air temperature has been used as an index to detect water deficit and its level in many crops, e.g., potato (Gerhards et al., 2016), wheat (Mon et al., 2016), bermudagrass (Emekli et al., 2007), soybean (Sayago et al., 2017) and sugarcane (Brunini and Turco, 2016). Leaf temperature can be measured using infrared thermometers, obtaining its value from an exact point or small areas through an image. That approach shows limitation due to 
spatial heterogeneity in the soil water condition and labor time (Sayago et al., 2017). Such condition is highlighted for sugarcane, grown in expansive areas, and gets intensified at the beginning of the cycle, given the lower soil cover by the crop (López et al., 2009).

An alternative for spatial heterogeneity is measuring the difference between leaf and air temperature using satellite or aircraft image within the thermal infrared range, considering the spatial temperature variability in the surface (Clarke, 1997; Torrion et al., 2014). Torrion et al. (2014) used suborbital image to determine the difference between leaf and air temperature for cotton under three water supply levels. Leaf and air temperature were the same in plots without water deficit. When half of the water demand was applied, the leaf temperature was between 3 and $11{ }^{\circ} \mathrm{C}$ above air temperature, the maximum exceeded value when irrigation was not used.

From the discussion above, this study aimed: (1) to identify water deficit based on the difference between leaf and air temperature in comparison with soil water content; and (2) to evaluate the use of land surface temperature obtained from surface image within the thermal infrared from satellite Landsat_8 to determine leaf temperature in commercial areas cultivated with sugarcane.

\section{Results and Discussion}

\section{Biometric measures}

Leaf area is responsible for gas exchange, in which water vapor exits $\left(\mathrm{H}_{2} \mathrm{O}_{v}\right)$ and carbon dioxide enters $\left(\mathrm{CO}_{2}\right)$. The area still receives the radiant energy used in photosynthesis. Stomatal closure inhibits gas exchange, promoting an increase in leaf temperature. LAl increase was marked up to 362 DAP in cane_plant, reaching the peak of 5.46 (Figure 1). Robertson et al. (1999) found maximum LAl values of 4.92 for irrigated crop and 4.11 for crop under water deficit. Keating et al. (1999), in turn, observed maximum LAl values around 7.0. The LAI of sugarcane (SP_79_1011) showed its maximum value in irrigated (6.48) compared to non_irrigated (6.33) system (Farias, 2001). Varela (2002) points out 7.08 as the maximum LAl of that crop, which can be reached at 288 days. Farias et al. (2007) detected maximum LAI between 3.5 and 4.0 for different irrigation levels and zinc rates.

\section{Air, leaf and surface temperature}

Plant transpiration is a component of the energy balance, which determines leaf temperature according to leaf anatomical factors (dimensions, pigmentation and mass), environmental factors (solar radiation, air speed, air temperature and air relative humidity) and biological factors (number and distribution of stomata) (Leuzinger et al., 2010). When water was limiting, transpiration decreased and leaf temperature increased (Wang and Gartung, 2010). In this study, the air temperature $\left(\mathrm{T}_{\mathrm{a}}\right)$ ranged from $28.3^{\circ} \mathrm{C}$, at the beginning of the cycle, to $31.3^{\circ} \mathrm{C}$, from 442 days after planting (DAP) to the end of the cycle (Figure 2a). Leaf temperature $\left(T_{L}\right)$, measured in the field, ranged from $27.1^{\circ} \mathrm{C}$ at the beginning of the evaluation (298 DAP), to values above $35^{\circ} \mathrm{C}$ from 442 to 474 DAP (Figure 2a). $T_{L}$ was lower than $\mathrm{T}_{\mathrm{a}}$ until $394 \mathrm{DAP}$, but after this date, the presence of a water deficit leads to a $T_{L}$ higher than $T_{a}$ (Figure 2a). Land surface temperature $\left(T_{s}\right)$ ranged from $26.5^{\circ} \mathrm{C}$, at $410 \mathrm{DAP}$, to a maximum value of $34.9{ }^{\circ} \mathrm{C}$, occurring at 506 DAP. Brightness temperature (TB) for band 10 (TB10) and 11 (TB11) were lower than $T_{a}, T_{L}$, and $T_{S}$ for all evaluated date (Figure 2a). In the absence and presence of water deficit, sugarcane plants reach average $T_{L}$ values around $27{ }^{\circ} \mathrm{C}$ and $32{ }^{\circ} \mathrm{C}$, respecively (Trentin et al., 2011).

The highest relative error occurred for TB10 and TB11 when $T_{L}$ was used as a reference (Figure $2 b$ ). The relative error occurred at the end of the cycle, with _6.88\% for band 10 , and $10.7 \%$ for band 11 . At 426 DAP, it was observed the maximum error of _42.2\%, occurring for band 11 (Figure $2 \mathrm{~b}$ ). The use of $\mathrm{T}_{\mathrm{S}}$ obtained from band 10 and 11 , soil cover factor and vapor pressure at atmosphere reduced the relative error in comparison with $T_{L}$, wherein in most of the periods analyzed, the error was lower than $10 \%$ (Figure $2 \mathrm{~b}$ ). In three samples, $T_{S}$ error was around $20 \%$ (Figure $2 \mathrm{~b}$ ). The moment at which $T_{L}$ was higher than $T_{a}$ indicates water deficit. The error associated with $T_{S}$ compared to $T_{L}$ can be related to the proportion of soil cover along the area, the surface energy balance, thermal properties of the surface, as crop albedo, weather conditions and surface roughness (García, 2012).

\section{Water deficit detection}

Leaf temperature $\left(T_{L}\right)$ was lower than air temperature $\left(T_{a}\right)$ from 298 to 394 DAP, period in which the water balance indicates a water surplus, supplying the total crop demand without water deficit (Figure 3a). With soil water deficit from 410 DAP, $T_{L}$ becomes higher than $T_{a}$, with constant $T_{L}$ increase from the difference of $1.86{ }^{\circ} \mathrm{C}$. The maximum difference, of $7.11{ }^{\circ} \mathrm{C}$, was reached at 474 DAP (Figure 3a). After this date, a 14_mm rainfall event occurred for the period 474_490 DAP (Figure 3b), which leads to a lower $T_{L}$ and $T_{a}$ difference. The two last samples had a continuous water deficit, but with decreased $T_{L}$ and $T_{a}$ difference, which can be caused by the ending of the cycle. In this moment, the crop reduced leaf area index to $\sim 2$ (Figure $3 b$ ). That is one of the first signs of continuous water deficit (Inman_Bamber, 2005), leading to increased crop albedo by less green leaves and lower crop maturity (Inman_Bamber et al., 2008; Pincelli and Silva, 2012). Sayago et al. (2017) observed an outlier for the relationship between temperature vegetation dryness index (TVDI) and relative evapotranspiration occurring after soybean reached maturity with leaf senescence, altering the surface energy balance.

The use of land surface temperature $\left(T_{S}\right)$ to obtain the difference from air temperature showed to be less sensitive for water supply throughout the evaluation period. In the first evaluation, the difference $\left(T_{S_{-}} T_{a}\right)$ was of $\_0.66^{\circ} \mathrm{C}$, which continued to reduce until $4.06^{\circ} \mathrm{C}$, with an increase of water surplus from $7 \mathrm{~mm}$ to $61 \mathrm{~mm}$ (Figure 4). At 410 DAP, the temperature difference becomes positive in $1.2{ }^{\circ} \mathrm{C}$, associated with water deficit (Figure 4). Continuous water deficit around $20 \mathrm{~mm}$ until 490 days after planting kept the $T_{S_{-}} T_{a}$ difference negative. In the last evaluated date, in turn, with an increase of water deficit to $34 \mathrm{~mm}$, the $\mathrm{T}_{\mathrm{S}_{-}} \mathrm{T}_{\mathrm{a}}$ difference indicates a positive difference of $1.74{ }^{\circ} \mathrm{C}$. Sayago et al. (2017) observed that the use of temperature vegetation dryness index (TVDI), obtained from $\mathrm{T}_{\mathrm{S}}$ range, does not represent properly the soil water content 


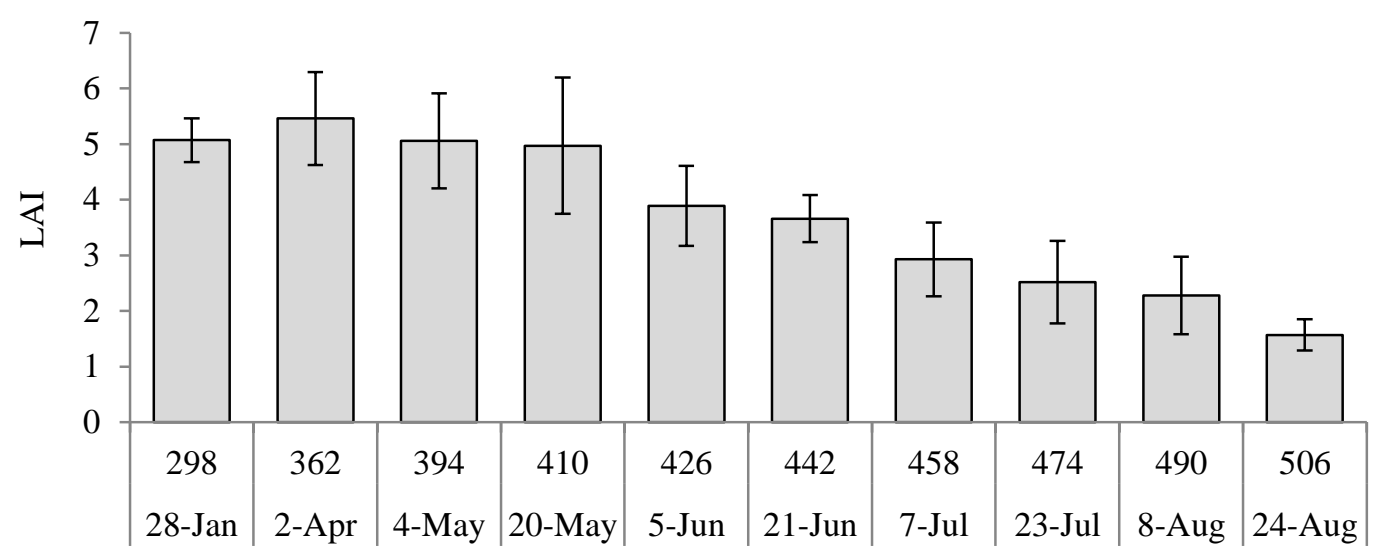

Fig 1. Leaf area index $\left(\mathrm{LAl}, \mathrm{m}^{2} \mathrm{~m}^{-2}\right)$ of sugarcane as a function of days after planting and dates. Error bars: standard deviation.
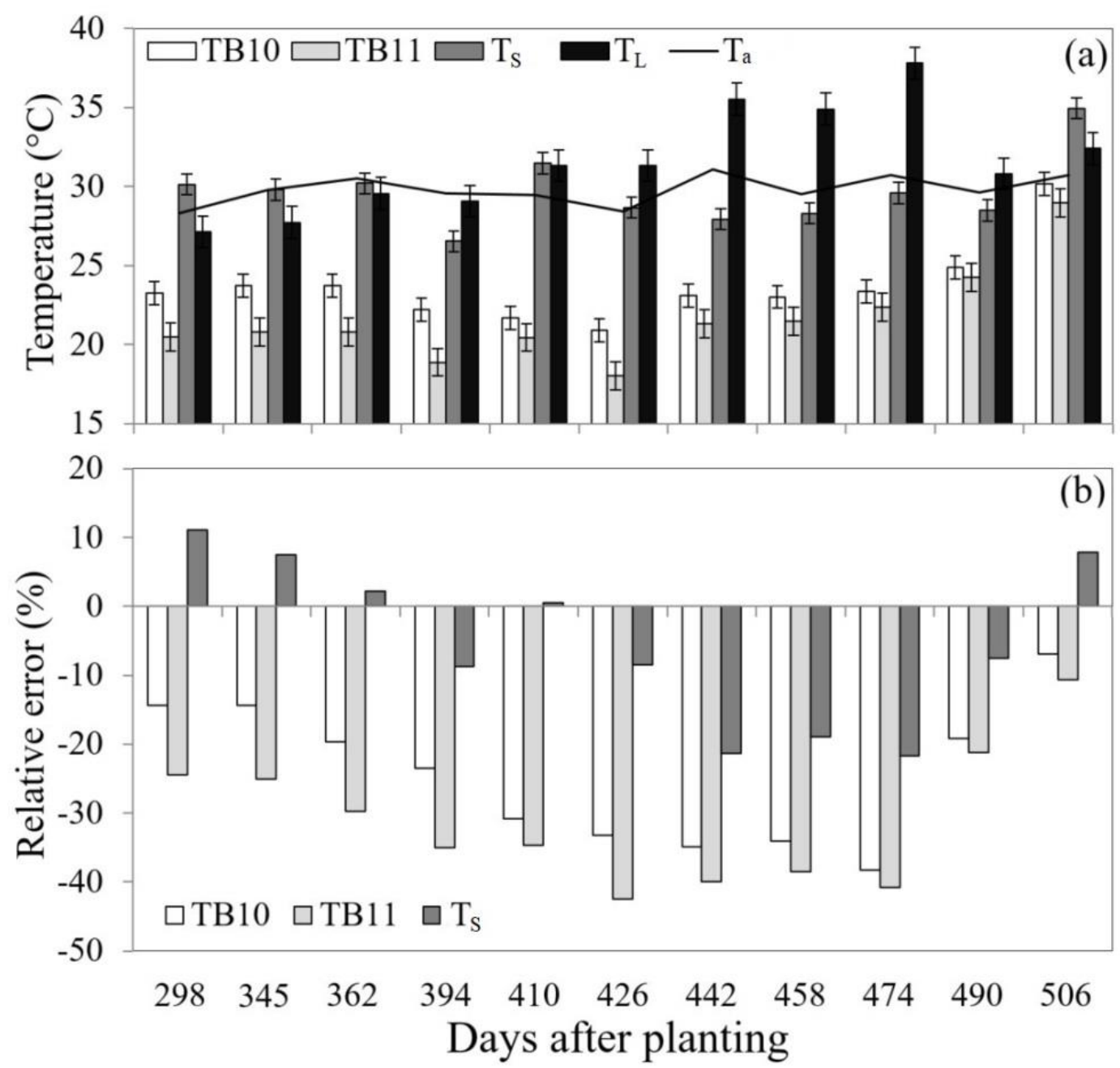

Fig 2. Air temperature $\left(T_{a}\right)(a)$, leaf temperature $\left(T_{L}\right)$, land surface temperature $\left(T_{S}\right)$ and brightness temperature for bands 10 (TB10) and 11 (TB11); relative error between $T_{S}$ (estimate from TB10 and TB11) and $T_{L}$ (b) measured from 298 to 506 days after planting for sugarcane. "Error bars: standard deviation. 

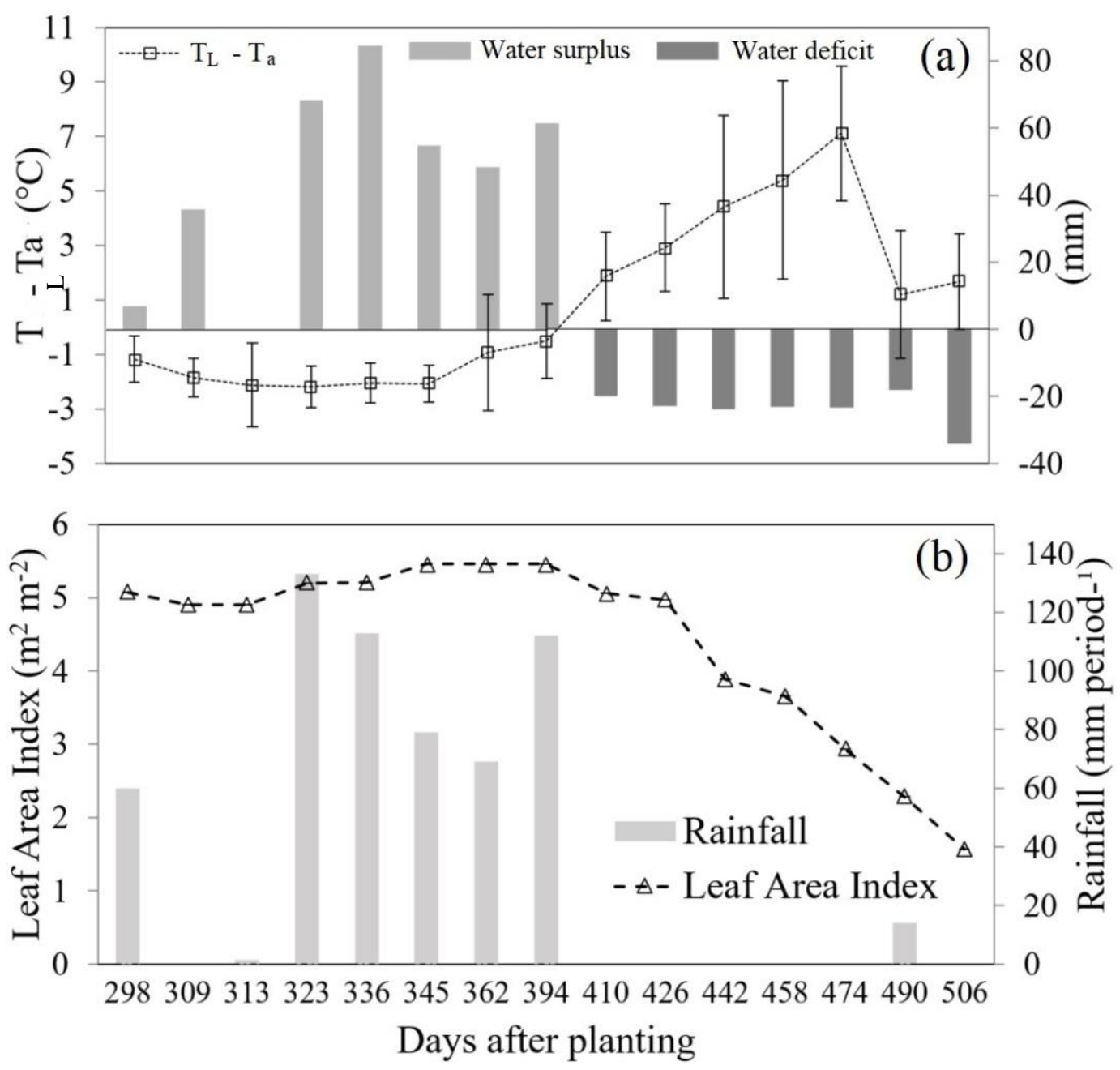

Fig 3. Leaf and air temperature difference measured at $13 \mathrm{~h}\left(T_{\llcorner} T_{a}\right)$, water surplus and deficit $(a)$, and rainfall and leaf area index (b) measured along the sugarcane growth from 298 to 506 days after planting. "Error bars: standard deviation.

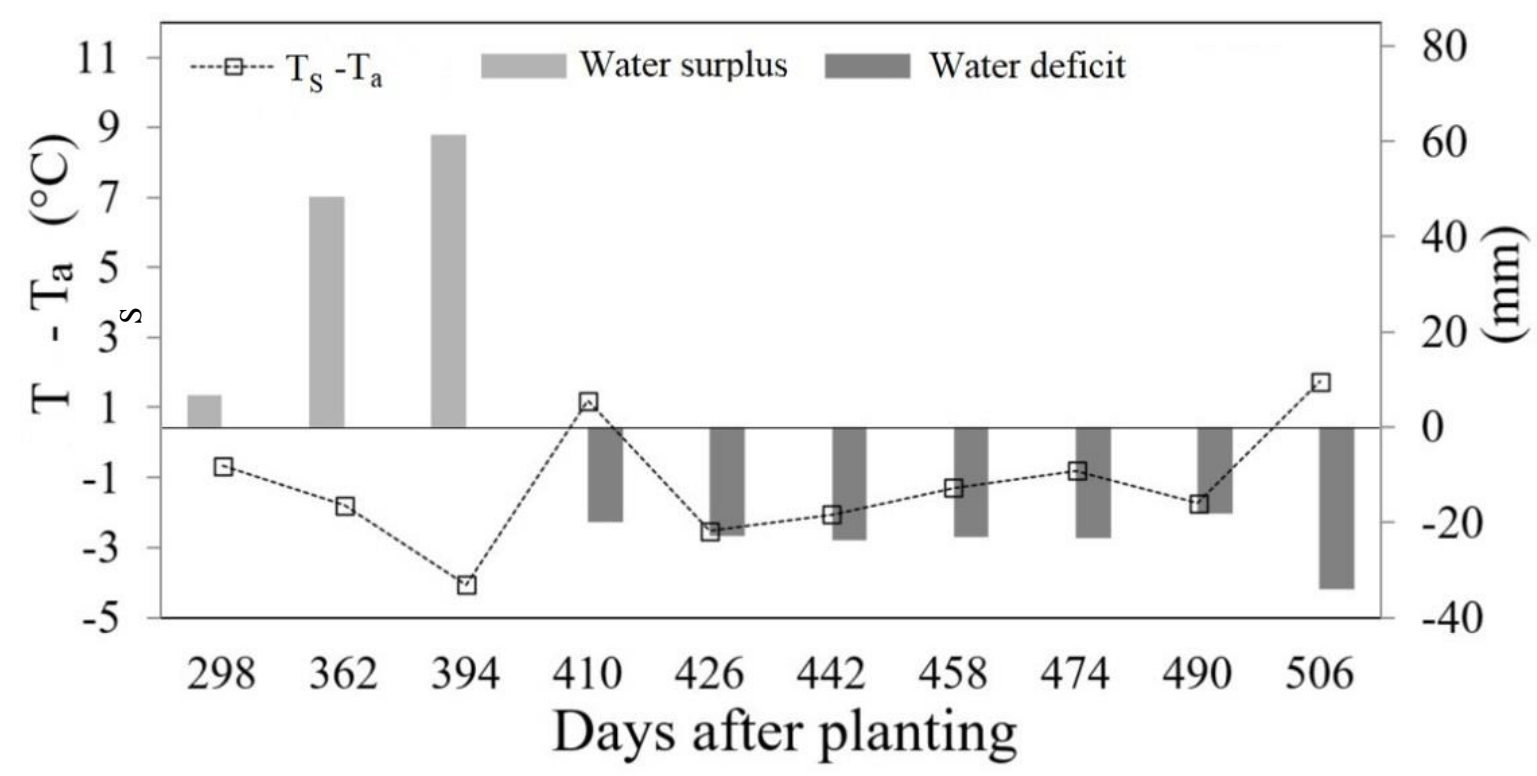

Fig 4. Surface temperature $\left(T_{S}\right)$ and air temperature $\left(T_{a}\right)$ difference measured at $13 \mathrm{~h}\left(T_{S_{-}} T_{a}\right)$; water surplus (WS) and deficit (WD) measured along the sugarcane growth from 298 to 506 days after planting. 


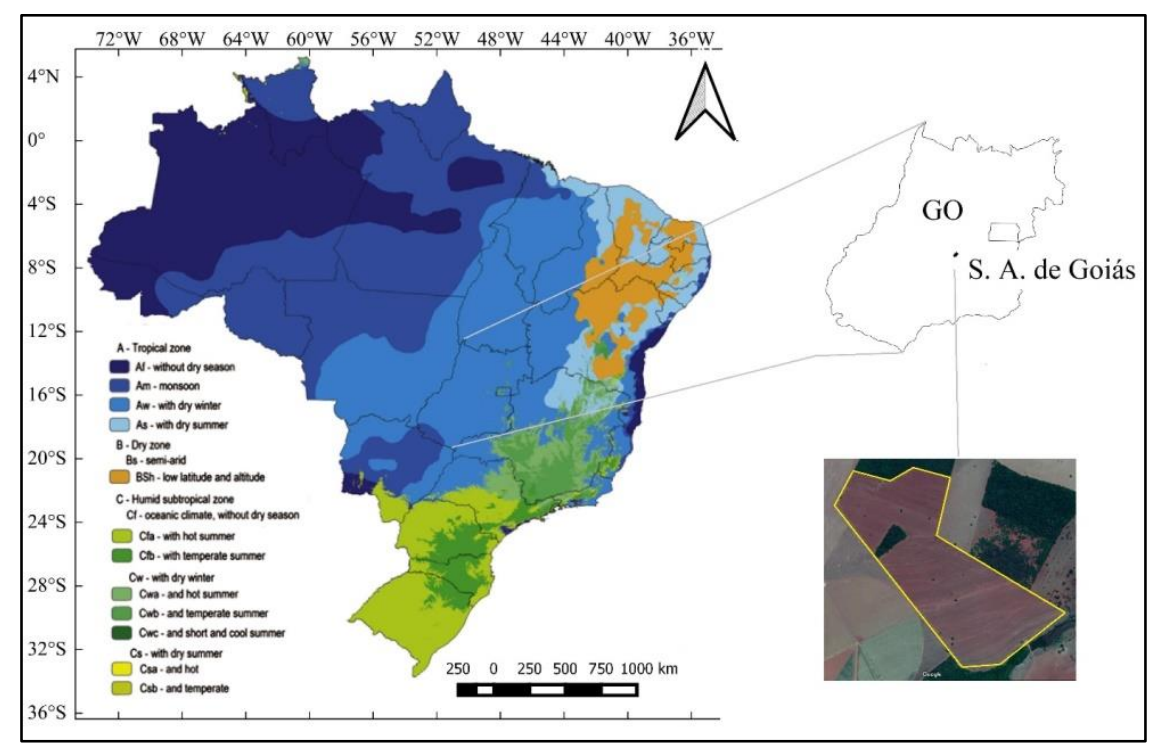

Fig 5. Location of field experiment for sugarcane in Santo Antônio de Goiás, GO. Köppen's climate classification adapted from Alvares et al. (2013).

when under high vegetation cover. Moreover, these authors observed an improvement between TVDI and relative crop evapotranspiration when the vegetation covered over $60 \%$ of the soil. The use of surface temperature from satellite Landsat_8 for agricultural areas can show uncertainties associated with estimation and calibration approach based on band 10 and 11. Yu et al. (2011) obtained a root mean square error of $1.0^{\circ} \mathrm{C}$ for four agricultural areas, where the error was associated with vapor pressure in the atmosphere. Besides that, LST was obtained from a pixel of $900 \mathrm{~m}^{2}$, where surrounding conditions can affect the surface temperature and delay the response for the crop water deficit, resulting in a higher error (Moreira and Galvíncio, 2007; Sayago et al., 2017). This is evidenced when analyzing the error from $T_{S_{-}} T_{L}$ and $T_{S_{-}} T_{a}$ difference. When the relative error for $T_{S}$ was lower (Figure 2b), as in 362 and 410 DAP, the crop clearly tended to be under limited and good water supply, respectively (Figure 4). Otherwise, when the water surplus and deficit were higher, respectively, at 394 and 506 DAP, even with a relative error around $8 \%$, the $T_{S_{-}} T_{a}$ difference correctly indicates the plant water status.

\section{Materials and Methods}

\section{Experimental site}

The field experiment was conducted in Santo Antônio de Goiás, Goiás State $\left(16.4894^{\circ} \mathrm{S}\right.$; $49.3129^{\circ} \mathrm{W} ; 769 \mathrm{~m}$ above sea level), in a commercial area with 194 ha (Figure 5). According to Köppen's classification, the climate of the region is Aw (Alvares et al., 2013). Mean annual air temperature was $23.0^{\circ} \mathrm{C}$, with the hottest (September) and coldest month (June) having, respectively, a mean air temperature of $31.7{ }^{\circ} \mathrm{C}$ and $14.4^{\circ} \mathrm{C}$. During the year, the rainy and dry periods are, respectively, from October to April and from May to September (INMET, 2018). Annual mean rainfall, relative humidity, and reference evapotranspiration were, respectively, $1498 \mathrm{~mm}$ year ${ }^{1}, 70 \%$ and $1559 \mathrm{~mm}$ year $^{-1}$ (Silva et al., 2012). In the area, the soil was classified as Ferralsol, with clayey texture (Silva et al., 2014). The cultivar grown was the CTC_4, which had excellent initial growth, with medium to late maturity and tolerance to drought (CTC, 2013).

\section{Plant measurements}

Ten points were sampled in the experimental area. Each point corresponded to two rows of eight linear meters. The plant data were obtained from January to August 2014, between 281 and 506 DAP, which corresponded to the end of the stem growth phase, i.e., the maturity phase. The procedure occurred in ten dates coincident with the passage of the satellite. The biometric indices evaluated were: i) Number of tillers per $\mathrm{m}^{2}$ (Nassif, 2012); ii) Number of green leaves: by counting the number of fully expanded green leaves; iii) Leaf area per tiller: obtaining the leaf area according to Hermann and Câmara (1999):

$L A=L \cdot W \cdot 0.75 \cdot(N+2) \quad[1]$

in which LA is the leaf area per tiller $\left(\mathrm{cm}^{2}\right), \mathrm{L}$ is leaf length +3 $(\mathrm{cm}), W$ is leaf width $+3(\mathrm{~cm}), 0.75$ the correction factor for sugarcane leaf area, and $N$ the number of open leaves with at least $20 \%$ green area; iv) Leaf area index (LAl, $\mathrm{m}^{2} \mathrm{~m}^{-2}$ ), estimated by equation [2]:

$L A I=\frac{N T \cdot L A}{S}$

Where NT is the number of tillers per $m^{2}\left(N T, m^{-2}\right)$, LA the leaf area per tiller $\left(\mathrm{m}^{2}\right)$ and $S$ the land surface $\left(\mathrm{m}^{2}\right)$.

\section{Leaf temperature measurement}

Plant leaf temperature was measured in the field, using a portable infrared thermometer (Minipa MT_330), with a resolution of $0.1{ }^{\circ} \mathrm{C}$ within the $\_60^{\circ} \mathrm{C}-550{ }^{\circ} \mathrm{C}$ range, and precision of $\pm 2{ }^{\circ} \mathrm{C}$. Measurements were done in the field at the same day satellite Landsat 8 took the image from the area, starting on 28 Jan 2014, 298 days after planting, until 24 Aug 2014, 506 days after planting, with a temporal resolution of 16 days. The cloud between 309 and 336 days after planting (Feb_Apr) limited the comparison of satellite images with field measurements. 
The spectral image was obtained from the satellite, in infrared bands $10(10.60-11.19 \mu \mathrm{m})$ and $11(11.5-12.51$ $\mu \mathrm{m})$, using four windows with a resolution of $100 \times 100 \mathrm{~m}$ over the sugarcane field. Each window was set to three pixels $(30 \times 30)$ and used to determine land surface temperature $\left(T_{s}\right)$. Bands $4(0.630-0.680 \mu \mathrm{m})$ and $5(0.845-$ $0.885 \mu \mathrm{m}$ ) were obtained to determine the normalized difference vegetation index (NDVI) for the sugarcane target area, using a $30 \times 30 \mathrm{~m}$ window. In the field, five plots with 12 plants were determined in each pixel area to measure leaf temperature and sugarcane growth. Leaf temperature was measured at a distance of $3 \mathrm{~cm}$ in four points along the leaf surface. In the initial evaluation, sugarcane was at the maximum growth rate, while the final evaluation corresponded to the maturity phase.

\section{Land surface temperature}

Land surface temperature $\left(T_{S},{ }^{\circ} \mathrm{C}\right)$ was estimated using the Split_Window algorithm (Rozenstein et al., 2014), which considers the brightness temperature of bands 10 and 11 from TIRS sensor, analyzing the mean and the difference of target surface emissivity, based on Eq. [3].

$T_{S}=T B_{10}+C_{1} \cdot\left(T B_{10}-T B_{11}\right)+C_{2} \cdot\left(T B_{10}-T B_{11}\right)^{2}+$ $C_{0}+\left(C_{3}+C_{4} \cdot W\right) \cdot(1-\varepsilon)+\left(C_{5}+C_{6} W\right) \cdot \Delta \varepsilon \quad$ [3] where: $\mathrm{TB}_{10}$ and $\mathrm{TB}_{11}$ are the brightness temperatures of bands 10 and $11\left({ }^{\circ} \mathrm{C}\right) ; \mathrm{C}_{0}, \mathrm{C}_{1}, \mathrm{C}_{2}, \mathrm{C}_{3}, \mathrm{C}_{4}, \mathrm{C}_{5}$, and $\mathrm{C}_{6}$ are parameters of the Split_Window algorithm, being, respectively,_0.268; 1.378; 0.183; 54.3; _2.238;_129.2; and 16.4 (Rajeshwari and Mani, 2014); $\varepsilon$ is the mean emissivity of bands 10 and $11 ; W$ is the vapor pressure in the atmosphere at the moment the image was taken from the satellite; and $\Delta \varepsilon$ is the emissivity difference between bands 10 and 11.

The brightness temperature (TB) of bands 10 and $11\left({ }^{\circ} \mathrm{C}\right)$ was obtained based on the spectral radiation $(L \lambda)$ (Eq. [4]) of the sensor and converted through the reverse of Planck's function (Eq. [5]):

$L \lambda_{i}=M_{L i} \cdot Q_{\text {cal }}+A_{L i}$.

$T B_{i}=\frac{K 2_{i}}{\ln \left(\frac{K 1_{i}}{L \lambda}+1\right)}+273.15$

where: $M_{\mathrm{Li}}$ is the multiplicative factor of resizing for band $\mathrm{i}$; $\mathrm{Q}_{\text {cal }}$ is the digital pixel number; $A_{L}$ is the specific additive scaling factor for band $i ; T B_{i}$ is the brightness temperature from satellite in band $\mathrm{i} ; \mathrm{K} 1$ and $\mathrm{K} 2$ are calibrated constants for band $i$; $L \lambda$ is the spectral radiation of the sensor in band $i$

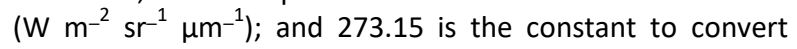
absolute temperature from Kelvin to ${ }^{\circ} \mathrm{Celsius}\left({ }^{\circ} \mathrm{C}\right)$.

The mean emissivity $(\varepsilon)$ and emissivity difference $(\Delta \varepsilon)$ in bands 10 and 11 were obtained from Eq. [6] and [7] using land surface emissivity (LSE) for each band. Land surface emissivity was quantified using reference values (Eq. [8]) and the soil:vegetation ratio, determined by soil cover factor (SCF) (Eq. [9]):

$\varepsilon=\frac{\left(L S E_{10}-L S E_{11}\right)}{2}$

$\Delta \varepsilon=L S E_{10}-L S E_{11} \quad$ [7]

$L S E_{i}=\varepsilon_{S}(1-S C F)+\varepsilon_{S} \cdot S C F$

$S C F=\frac{N D V I-N D V I_{S}}{N D V I_{V}-N D V I_{S}}$

where: $L_{S E} 10$ and $L S E_{11}$ are, respectively, the emissivity of bands 10 and $11 ; \varepsilon_{\mathrm{s}}$ e $\varepsilon_{\mathrm{v}}$ are, respectively, parameters for soil and vegetation emissivity for bands $10 \quad\left(\varepsilon_{\mathrm{s}}=0.971\right.$; $\left.\varepsilon_{\mathrm{v}}=0.987\right)$ and $11\left(\varepsilon_{\mathrm{s}}=0.977 ; \varepsilon_{\mathrm{v}}=0.989\right) ; \mathrm{NDVI}$ is the normalized difference vegetation index for the sugarcane target area (NDVI), from uncovered soil (NDVI $)$, and from a natural forest $\left(\mathrm{NDVI}_{\mathrm{V}}\right)$. NDVI was obtained from bands 4 and 5 from OLI sensor for sugarcane, soil and forest. The NDVI was used to estimate sugarcane leaf area index (Pereira et al., 2016).

The atmosphere's vapor content $\left(\mathrm{w}, \mathrm{g} \mathrm{cm}^{-2}\right)$ was obtained from the Leckner equation (Iqbal, 1983), shown in Eq. [10]:

$w=0.493 \cdot R H \cdot \frac{e_{s}}{T_{a}}$

where: $\mathrm{RH}$ is the relative humidity (absolute value); $\mathrm{e}_{\mathrm{s}}$ is the water vapor pressure in the saturation $(\mathrm{hPa})$; and $\mathrm{T}_{\mathrm{a}}$ is the air temperature (K).

\section{Soil water deficit}

Water deficit was quantified according to Thornthwaite and Mather's (1955) water balance, using $100 \mathrm{~mm}$ as a maximum soil water holding capacity. Reference evapotranspiration was obtained from the method proposed by Hargreaves and Samani (1985), using maximum, mean and minimum air temperature, in addition to extraterrestrial solar radiation, obtained based on the day of the year and latitude. These weather variables, along with rainfall, used as input in the water balance, were measured near the area of the field experiment.

\section{Correlation and error analyses}

Temperature values from satellite image using bands 10,11 and land surface temperature $\left(T_{S}\right)$ were quantified by the relative error (RE\%) (Eq. [11]) in comparison with leaf temperature measured in the field.

$R E \%=\frac{T_{S}-T_{L}}{T_{L}} \cdot 100$

where $T_{S}$ represents the surface temperature, quantified based on bands 10,11; and $T_{L}$ is the leaf temperature measured in the field.

\section{Conclusion}

This research found that the difference between leaf and air temperature can be used to identify water deficit in commercial sugarcane areas, with the index being sensitive to the variation of soil water content. In contrast, the higher error between land surface temperature (obtained from brightness temperature) and leaf temperature limited the application of this approach to identify water deficit for sugarcane, except in the moment of higher water deficit or surplus. Further investigation is needed to estimate land surface temperature based on satellite image with higher spatial and temporal frequency, considering the crop stage, soil cover proportion, weather conditions and surface properties.

It is important to emphasize that $T_{S}$ uses in its algorithm the estimation of brightness temperature from bands 10 and 11, since when only band 11 is applied, $T_{S}$ values tended to be smaller. Furthermore, calibration uncertainty was more closely associated with the data of band 11 , since this band is more affected by the absorption of radiation by the atmospheric water vapor, which implies larger errors related to the atmospheric profile in the acquisition of surface temperature. 
Inman-Bamber NG, Smith DM (2005) Water relations in sugarcane and response to water deficits. Field Crop Res. 92: 185-202.

To the Federal University of Goiás (UFG) and the Postgraduate Program in Agronomy of UFG. To the Coordination for the Improvement of Higher Education Personnel (CAPES), for the scholarship. To the Goiás Research Foundation (FAPEG), for the study support. To the "Centro Álcool" plant, for the crop area where the research was carried out. Finally, to other collaborators of the Research Center on Climate and Water Resources of the "Cerrado" (NUCLIRH).

\section{References}

Alvares CA, Stape JL, Sentelhas PC, Gonçalves JLM, Sparovek G (2013) Köppen's climate classification map for Brazil. Meteorol Z. 22: 711-728.

Araújo TL, Di Pace FT (2010) Valores instantâneos da temperatura da superfície terrestre na cidade de Maceió-AL utilizando imagens do satélite TM/LANDSAT 5. Rev bras Geogr Física. 3: 104-111.

Brunini RG, Turco JEP (2016) Water stress indices for the sugarcane crop on different irrigated surfaces. $R$ bras Eng Agr Amb. 20: 928-929.

Centro de tecnologia canavieira-CTC (2013) Variedades CTC. Rev CTC. $<$ http://www.ctcanavieira.com.br/downloads/variedades2 013web3.pdf>

Clarke TR (1997) An empirical approach for detecting crop water stress using multispectral airbone sensors. Horticul Tech. 7(1): 9-16.

CONAB (2018) Séries históricas das safras: cana-de-açúcar. <https://www.conab.gov.br/index.php/infoagro/safras/serie-historica-das-safras?start=20>

Emekli Y, Bastug R, Buyuktas D, Emekli N Y (2007) Evaluation of a crop water stress index for irrigation scheduling of bermuda grass. Agr Water Manag. 90: 205-212.

Farias CHA (2001) Desempenho morfofisiológico da cana-deaçúcar em regime irrigado e de sequeiro na Zona da Mata paraibana. (Dissertação de Mestrado), Universidade Federal da Paraíba (UFPA). 78 p.

Farias CHA, Dantas Neto J, Fernandes PD, Gheiy HR (2007) Índice de área foliar em cana-de-açúcar sob diferentes níveis de irrigação e zinco na Paraíba. Rev Caatinga. 20(4): 45-55.

García GS (2012) Assessment of vegetation indexes from remote sensing: theoretical basis. Options Méditerranéennes. Série b. Etud Rech 67: 65-75.

Gerhards M, Rock G, Schlerf M, Udelhoven T (2016) Water stress detection in potato plants using leaf temperature, emissivity, and reflectance. Int J Appl Earth Obs. 53: 27-39.

Gilbert ME, Holbrook NM, Zwieniecki MA, Sadok W, Sinclair TR (2011) Field confirmation of genetic variation in soybean transpiration response to vapor pressure deficit and photosynthetic compensation. Field Crop Res. 124: 8592.

Hargreaves GH, Samani ZA (1985) Reference crop evapotranspiration from temperature. Appl Eng Agric. 1(2): 96-99.

Hermann ER, Câmara, GMS (1999) Um método simples para estimar a área foliar de cana-de-açúcar. Rev STAB. 17: 3234.
Inman-Bamber NG, Bonnett GD, Spillman MF, Hewitt ML, Jackson J (2008) Increasing sucrose accumulation in sugarcane by manipulating leaf extension and photosynthesis with irrigation. Aust J Agr Res. 59: 13-26.

Instituto Nacional de Meteorologia - INMET (2018) Normais climatológicas 2018. <http://www.inmet.gov.br/portal/index.php?r=clima/nor maisclimatologicas>

Iqbal M (1983) An introduction to solar radiation. Library of congress cataloging in publication data. Academic Press Canadian. 390 p.

Keating BA, Robertson RC, Muchow RC, Huth NI (1999) Modeling sugar cane production systems I - Development and performance of the sugar cane module. Field Crop Res. 61: 253-271.

Leuzinger S, Vogt R, Körner C (2010) Tree surface temperature in an urban environment. Agr Forest Meteorol. 150: 56-62.

López RL, Ramírez RA, Peña MAV, Cruz IL, Cohen IS (2009) Índice de estrés hídrico como un indicador del momiento de riego en cultivos agrícolas. Agr Téc México. 35(1): 91111.

Mon J, Bronson KF, Hunsaker DJ, Thorp KR, White JW, French AN (2016) Interactive effects of nitrogen fertilization and irrigation on grain yield, canopy temperature, and nitrogen use efficiency in overhead sprinkler-irrigated durum wheat. Field Crop Res. 191: 5465.

Monteiro LA, Sentelhas PC (2017) Sugarcane yield gap: can it be determined at national level with a simple agrometeorological model? Crop Pasture Sci. 68: 272-284. doi.org/10.1071/cp16334.

Moreira EBM, Galvíncio JD (2007) Espacialização das temperaturas à superfície na cidade do recife, utilizando imagens TM-LANNDSAT 7. Rev Geogr. 24: 101-115.

Nassif DSP, Marin FR, Pallone WJF, Resende RS, Pellegrino GQ (2012) Parametrização e avaliação do modelo DSSAT/CANEGRO para variedades brasileiras de cana-deaçúcar. Pesqui Agropecu Bras. 47(6): 311-318.

Oliveira LMM, Montenegro SMGL, Antonino ACD, Silva BB da, Machado CCC, Galvíncio JD (2012) Análise quantitativa de parâmetros biofísicos de bacia hidrográfica obtidos por sensoriamento remoto. Pesqui Agropecu Bras. 47(9): 1209-1217.

Pereira R M, Casaroli D, Vellame L, Alves Junior J, Evangelista AWP (2016) Sugarcane leaf area estimate obtained from the corrected normalized difference vegetation index (NDVI). Pesqui Agropecu Trop. 46: 140-148.

Pincelli RP, Silva MA (2012) Alterações morfológicas foliares em cultivares de cana-de-açúcar em resposta à deficiência hídrica. Biosci J. 28(4): 546-556.

Rajeshwari A, Mani D (2014) Estimation of land surface temperature of Dindigul district using Landsat-8 data. Int J Res Eng Tech. 3(5): 122-126.

Robertson MJ, Inmam-Bamber NG, Muchow RC, Wood AW (1999) Physiology and productivity of sugar cane with early and mid-season water deficit. Field Crop Res. 64: 211-227.

Rozenstein O, Qin Z, Derimian Y, Karnieli A (2014) Derivation of land surface temperature for Landsat- 8 tirs using a split window algorithm. Sensors. 14: 5768-5780. 
Sayago S, Ovando G, Bocco M (2017) Landsat images and crop model for evaluating water stress of rainfed soybean. Remote Sens Environ. 198: 30-39.

Sepulcre-Cantó G, Zarco-Tejada PJ, Jiménez-Muñoz JC, Sobrino JA, Miguel E, Villalobos FJ (2006) Detection of water stress in an olive orchard with thermal remote sensing imagery. Agr Forest Meteorol. 136: 31-44.

Silva SC, Heinemann AB, Paz RLF, Amorim AO (2014) Informações meteorológicas para pesquisa e planejamento agrícola, referentes ao município de Santo Antônio de Goiás, GO, 2012. Santo Antônio de Goiás: Embrapa Arroz e Feijão. 29 p.

Silva TGF, Moura MSB, Zolnier S, Carmo JFA, Souza LSB (2012) Biometria da parte aérea da cana soca irrigada no submédio do Vale do São Francisco. Rev Cien Agron. 43(3): 500-509.

Sousa LM, Campos PF, Alves Junior J, Casaroli D, Evangelista AWP (2017) Produtividade de diferentes variedades de cana-de-açúcar submetidas à condições de déficit hídrico. Global Sci Tech. 10: 84-94.
Torrion JA, Maas SJ, Guo W, Bordovsky JP, Cranmer AM (2014) A three-dimensional index for characterizing crop water stress. Remote Sens-Basel. 6: 4025-4042.

Trentin R, Zolnier S, Ribeiro A, Steidle Neto AJ (2011) Transpiração e temperatura foliar da cana-de-açúcar sob diferentes valores de potencial matricial. Eng AgrJaboticabal. 31(6): 1085-1095.

Yu X, Guo X, Wu Z (2014) Land surface temperature retrieval from Landsat- 8 Tirs-comparison between radiative transfer equation-based method, split window algorithm and single channel method. Remote Sens-Basel. 6: 98299852.

Wang D, Gartung J (2010) Infrared canopy temperature of early-ripening peach trees under postharvest deficit irrigation. Agr Water Manage. 97: 1787-1794. 